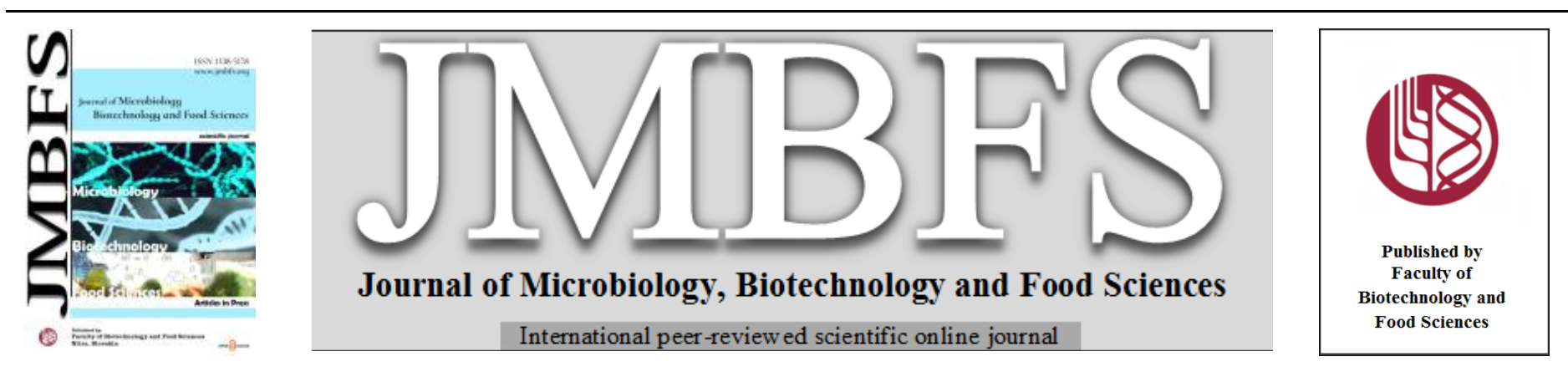

\title{
MONITORING OF ORGANIC VOLATILE COMPOUNDS IN CRAFT BEERS DURING FERMENTATIVE PROCESS
}

\author{
Gisele Gonçalves Bortoleto $^{1 *}$, Winston Pinheiro Claro Gomes ${ }^{1}$
}

$\operatorname{Address}($ es): Dra. Gisele Gonçalves Bortoleto

${ }^{1}$ State Center of Technological Education "Paula Souza“/CEETEPS, Tecnollogy Collegy of Piracicaba "Dep. Roque Trevisan“, Department of Food Technology, Av. Diácono Jair de Oliveira n.651, 13414-155, Piracicaba, São Paulo, Brazil, +55(19) 3413-1702.

*Corresponding author: gisele.bortoleto@fatec.sp.gov.br

https://doi.org/10.55251/jmbfs.4761

\section{ARTICLE INFO}

Received 11.5. 2021

Revised 21.9. 2021

Accepted 24. 9. 2021

Published 1. 2. 2022

Regular article

OPEN $\partial_{\text {ACCESS }}$

\begin{abstract}
The present study aimed to evaluate the formation of volatile organic compounds (VOCs) during the fermentation process of three different craft beers, using gas chromatography with headspace sampling. The production of VOCs, which are largely responsible for the flavors of the drink, makes up unique organoleptic characteristics for each beer. In this work, it was possible to observe the different profiles for the Pilsen, Witbier and IPA style beers, when quantifying the analytes methanol, ethanol, n-propanol, iso-butanol, 3-methyl1-butanol (iso-amyl alcohol), acetaldehyde, ethyl acetate and iso-amyl acetate. Pilsen beer, with low fermentation, presented the ethanol content in the same concentration range as Witbier beer, as expected, but with higher alcohols and lower esters than the other two. Witbier and IPA beers, both of high fermentation, presented isoamyl alcohol concentration above expectations, while IPA beer, present higher concentrations of n-propanol, ethyl acetate and isoamyl acetate in relation to Pilsen and Witibier, which is related to the complexity of its recipe.
\end{abstract}

Keywords: Craft beer, Volatile organic compounds, Gas chromatography, Headspace

\section{INTRODUCTION}

The Brazilian Association of the Brewing Industry, based on data from the Ministry of Agriculture, Cattle and Supplying (MAPA), points to Brazil as the third largest beer producer in the world, behind only China and the United States. Still, considering the great growth in the number of breeries and beer registrations that has been shown to be sustained in decades, the country may reach the mark of 7,504 breweries in 2025 , if the growth rate of $36 \%$ of the last five years is maintained, which surpasses the number of US breweries in the last available balance of 2018 with 7,346 breweries (Cervbrazil, 2020).

Beer, considered a complex sample, is defined as the beverage resulting from fermentation, from brewer's yeast, malted barley wort or malt extract, previously submitted to a cooking process added with hops or hop extract, hypothesis in that a part of the malted barley or malt extract may be partially replaced by a brewing assistant (Brazil, 2019).

Today there are countless styles that can be classified in different ways, but, considering the fermentation temperature, they are divided into two large families, namely Ales and Lagers. The brazilian Pilsen style beers, one of the most consumed in Brazil and in the world, is a Lager beer produced in low temperatures, with a clear and limpid aspect. Witbier and IPA style beers, from the Ales family, are produced at high fermentation temperatures, but differ from each other in several aspects. The Belgian school's Witibier is a beer produced with a percentage of unmalted wheat and they are seasoned with orange peel and coriander seed. This beer is very light, cloudy, low body and low bitterness, containing a fruity and spices flavor. Indian Pale Ale (IPA), from the English school, obtains its characteristics largely from hops, together with the herbal, citrus, resinous and bitter flavors, presenting a higher alcohol content (Preedy, 2009; Ambev, 2019).

Chemically, there are several compounds that define the unique flavors of each beer. Although ethanol, carbon dioxide and glycerol are the primary metabolic products produced by yeast during fermentation of the wort, they have little impact on the final flavor of the beer, although they influence its overall character. Higher alcohols, esters, vicinal diketones (VDKs) and other carbonyls such as acetaldehyde and sulfur compounds (inorganic and organic) are the main elements produced by yeast and these constituents determine the final quality of the product (Stewart, 2017). Many of them are known as volatile organics compounds (VOCs) and are of great relevance since they are the main elements of flavor and off-flavor of beers, also called attributes and defects, respectively (Preedy, 2009; Pires \& Brányik, 2015).
Among the chemical analysis techniques that quantify VOCs, gas chromatography occupies a prominent place due to the efficiency with which it performs separation, identification and determination of chemical components in complex mixtures (Collins, Braga \& Bonato, 2006; Skoog et al., 2017). Allied to GC, headspace sampling has been widely used for analysis of samples that may contaminate the chromatographic system and that cannot be injected directly into the column, as is the case with beers (Tian, 2010; Chen, 2018; Anderson, 2019; Gomes, Yoshinaga \& Bortoleto, 2020).

Thus, in this work, the fermentation process of three different craft beers were monitored, namely Pilsen, Witbier and IPA, in order to evaluate the formation of acetaldehyde, ethyl acetate, isoamyl acetate, methanol, ethanol, n-propanol, isobutanol and isoamyl alcohol in each of them, seeking a better understanding of the characteristics that distinguish each of them.

\section{MATERIAL AND METHODS}

All analyzes were conducted at the FATEC Piracicaba "Dep. Roque Trevisan" Paula Souza Center.

\section{Samples}

Samples of Pilsen and IPA beers were supplied by 2 microbreweries in the region. Samples of Witbier beer were collected at the Food Laboratory of FATEC Piracicaba, where it was produced.

\section{Production of Witbier beer}

For the wort was used 35 liters of water, $2.5 \mathrm{~kg}$ of pilsen malt, $2 \mathrm{~kg}$ of light wheat malt, $500 \mathrm{~g}$ of oat flakes and $20 \mathrm{~g}$ of Hallertau Tradition hops - T90 (5.4\% per year). As spices, $30 \mathrm{~g}$ of crushed coriander seeds, $10 \mathrm{~g}$ of crushed juniper, $20 \mathrm{~g}$ of lemon zest and $30 \mathrm{~g}$ of pear orange zest were added. The yeast type ALE used was T58 from Fermentis. Brazing was carried out in multi-steps, $52{ }^{\circ} \mathrm{C}$ for 10 minutes, $63{ }^{\circ} \mathrm{C}$ for 40 minutes, $72{ }^{\circ} \mathrm{C} 30$ minutes, then increasing $1{ }^{\circ} \mathrm{C}$ per minute, maintaining $78^{\circ} \mathrm{C}$ for 10 minutes with the recirculation pump on.

Fermentation was carried out for 7 days at $20{ }^{\circ} \mathrm{C}$, followed by 15 days for maturation at $5{ }^{\circ} \mathrm{C}$. The beer was bottled with the addition of primming $\left(9 \mathrm{~g} \mathrm{~L}^{-1}\right)$ for secondary fermentation for another 7 days at $20^{\circ} \mathrm{C}$. 


\section{Chemical analysis}

For the analyzes, all samples were collected daily (with the exception of sampling on some Saturdays and Sundays) and analyzed in triplicate on the same day.

The beers were analyzed for the concentration of methanol, ethanol, highe alcohols (propanol, iso-butanol, iso-amyl), esters (ethyl acetate and isoamyl acetate) and acetaldehyde, after being previously decarbonated for 5 minutes under mechanical stirring (Gomes, Yoshinaga \& Bortoleto, 2020). A Clarus 600 gas chromatograph, PerkinElmer, was used, with headspace sampling using an automatic sampler model CTC Analytics, Pal System. The chromatographic column was HP-INNOWAX $(30 \mathrm{~m} \times 0.25 \mathrm{~mm} \times 0.25 \mu \mathrm{m})$ from Agilent, and the conditions were optimized (recovery test and $2^{3}$ factorial planning for the evaluation of the headspace sampling conditions), according to Bortoleto \& Gomes (2020).

Analyte quantifications were performed based on external analytical curves of five standard concentration points, all prepared in $5 \%(\mathrm{v} / \mathrm{v})$ ethanol, with the exception of the ethanol analytical curve, which was prepared in deionized water The retention times (TR), concentration ranges and correlation coefficients obtained are shown in Table 1

Table 1 Retention time, concentration range, line equation, correlation coefficient.

\begin{tabular}{|c|c|c|c|c|}
\hline Compounds & $\mathrm{TR}(\mathrm{min})$ & Concentration range $\left(\mathrm{mg} \mathrm{L}^{-1}\right)$ & Line equation & $\mathrm{R}^{2}$ \\
\hline Acetaldehyde & 1.37 & $1.15-46.00$ & Area $=43.75+133.70 \mathrm{C}\left(\mathrm{mg} \mathrm{L}^{-1}\right)$ & 0.995 \\
\hline Ethyl acetate & 2.09 & $1.08-43.12$ & Area $=58.12+206.57 \mathrm{C}\left(\mathrm{mg} \mathrm{L}^{-1}\right)$ & 0.984 \\
\hline Methanol & 2.20 & $5.25-42.00$ & Area $=2.16+10.11 \mathrm{C}\left(\mathrm{mg} \mathrm{L}^{-1}\right)$ & 0.995 \\
\hline Ethanol $^{\mathrm{a}}$ & 2.64 & $0.25-10.00^{\mathrm{a}}$ & Area $=139.09+5859.50 \mathrm{C}(\mathrm{v} / \mathrm{v})$ & 0.999 \\
\hline Propanol & 4.08 & $11.99-59.95$ & Area $=7.26+37.24 \mathrm{C}\left(\mathrm{mg} \mathrm{L}^{-1}\right)$ & 0.981 \\
\hline Iso-Butanol & 5.09 & $11.79-58.95$ & Area $=143.39+71.34 \mathrm{C}\left(\mathrm{mg} \mathrm{L}^{-1}\right)$ & 0.974 \\
\hline Isoamyl acetate & 5.51 & $0.61-24.24$ & Area $=176.49+158.18 \mathrm{C}\left(\mathrm{mg} \mathrm{L}^{-1}\right)$ & 0.991 \\
\hline 3-methyl-1-butanol (Iso-amyl alcohol) & 6.90 & $55.25-276.25$ & Area $=-38.64+80.22 \mathrm{C}\left(\mathrm{mg} \mathrm{L}^{-1}\right)$ & 0.986 \\
\hline
\end{tabular}

\section{RESULTS AND DISCUSSION}

Fermentation

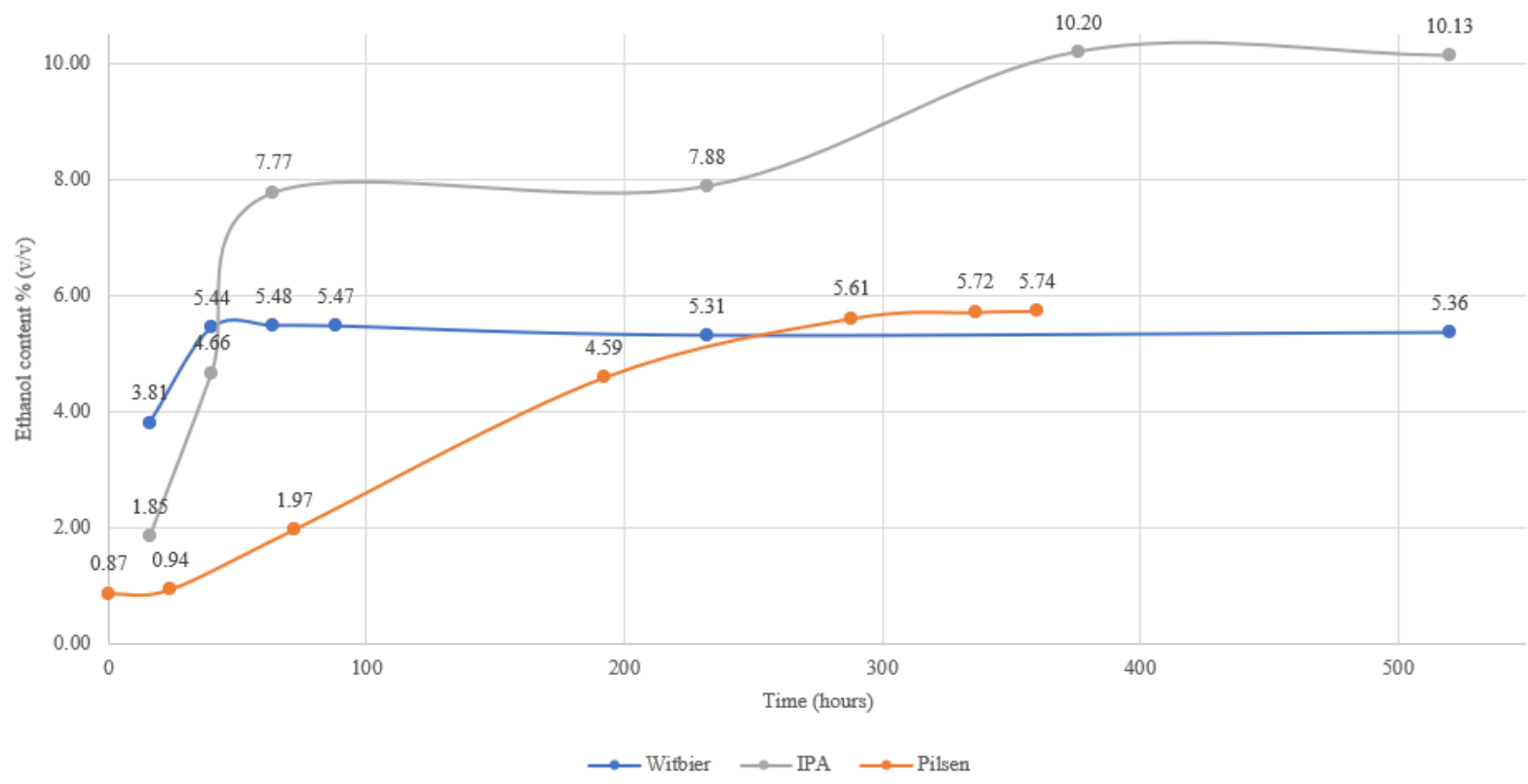

Figure 1 Formation of ethanol during the fermentation process of three different craft beers
Considering that the concentration of ethanol in beers is in the order of percentage, while that of the other analytes under study is in the order of $\mathrm{mg} \mathrm{L}^{-1}$, this alcohol was quantified separately. Figure 1 shows the formation of ethanol over time, until the day of the bottling. 
Table 2 Final levels $\left(\mathrm{mg} \mathrm{L}^{-1}\right)$ of volatile organic compounds in craft beers.

\begin{tabular}{lccc}
\hline Analytes & Pilsen & Witbier & $\mathrm{IPA}$ \\
\hline Acetaldehyde & 7.75 & 5.20 & 4.64 \\
\hline Ethyl acetate & 19.17 & 4.15 & 32.27 \\
\hline Methanol & $\mathrm{ND}^{\mathrm{a}}$ & $\mathrm{ND}^{\mathrm{a}}$ & $\mathrm{ND}^{\mathrm{a}}$ \\
\hline Propanol & $\mathrm{ND}^{\mathrm{a}}$ & 16.74 & 41.53 \\
\hline Iso-butanol & $\mathrm{ND}^{\mathrm{a}}$ & 47.03 & 38.58 \\
\hline Isoamyl acetate & 3.25 & $\mathrm{ND}^{\mathrm{a}}$ & 3.88 \\
\hline Isoamyl alcohol & $\mathrm{ND}^{\mathrm{a}}$ & 102.92 & 105.20
\end{tabular}

Source: Authors. ${ }^{\mathrm{a} N D}$ : Not detected

In the case of Pilsen beer, it is worth noting that the final concentrations of all quantified analytes (Sensory threshold of acetaldehyde: $20-25 \mathrm{mg} \mathrm{L}^{-1}$, ethy acetate: $30 \mathrm{mg} \mathrm{L}^{-1}$ and isoamyl acetate: $0,5-1,7 \mathrm{mg} \mathrm{L}^{-1}$ ) are close to the limits of sensory perception established in the literature (Meilgaard, Reid \& Wyborski, 1982; Kobayashi, Shimizu \& Shioya, 2008; Pires \& Brányik, 2015; Troilo et al., 2019).

With regard to the total higher alcohols present in beers, which are the most abundant organoleptic compounds in the drink (Pires \& Brányik, 2015), the results corroborate with the literature regarding the quantification of n-propanol (4 - $\left.48 \mathrm{mg} \mathrm{L}^{-1}\right)$, isobutanol $\left(4-57 \mathrm{mg} \mathrm{L}^{-1}\right)$ and isoamyl alcohol $\left(25-123 \mathrm{mg} \mathrm{L}^{-1}\right)$ (Preddy, 2009; Pires \& Brányik, 2015; Troilo et al., 2019). Anyway, it is worth mentioning that the Witbier and IPA beers presented concentrations of isoamyl alcohol above the organoleptic threshold of $70 \mathrm{mg} \mathrm{L}^{-1}$, which can negatively affect the flavor of the beer (Kobayashi, Shimizu \& Shioya, 2008; Troilo et al., 2019).

With regard to the presence of ethyl acetate, it is important to highlight the concentration of $32 \mathrm{mg} \mathrm{L}^{-1}$ of this analyte in IPA beer, which, according to Kobayashi, Shimizu \& Shioya (2008) and Troilo et al. (2019), would be above the limit of sensory perception. The authors state that beers containing ethyl acetate with concentrations greater than $30 \mathrm{mg} \mathrm{L}^{-1}$ may have a sweet and solvent flavor, which is not desirable for the drink. However, concentrations between 10 and $80 \mathrm{mg} \mathrm{L}^{-1}$ of ethyl acetate are usually found in the most diverse types of beers (Kobayashi, Shimizu \& Shioya, 2008; Preedy, 2009; Nešpor et al., 2018; Troilo et al., 2019; Bortoleto \& Gomes, 2020).

To comparatively analyze the VOCs formation behavior in the different beers, we can observe the different profiles obtained, as shown in Figures 2, 3 and 4, for the Pilsen, Witbier and IPA beers, respectively.

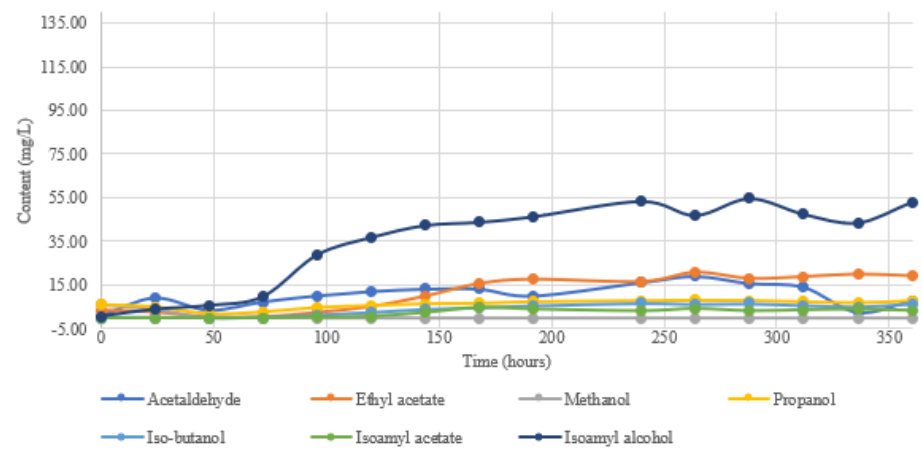

Figure 2 Formation of VOCs in the fermentation process of Pilsen beer.

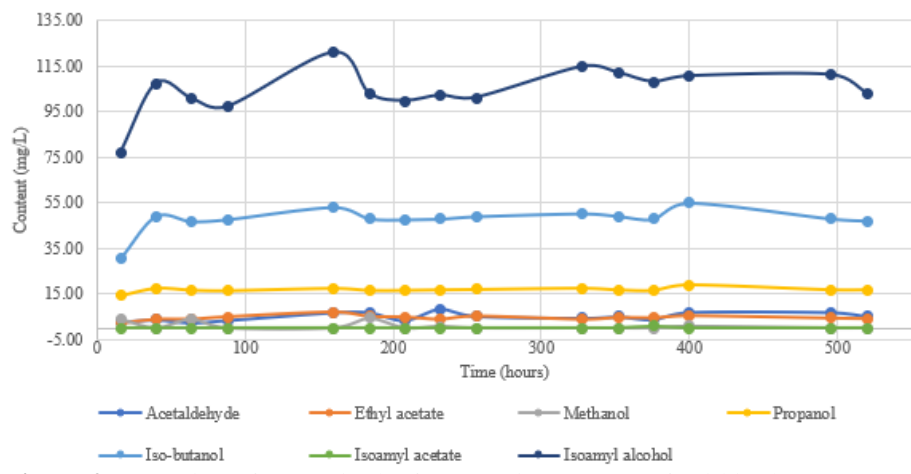

Figure 3 Formation of VOCs in the fermentation process of Witbier beer.

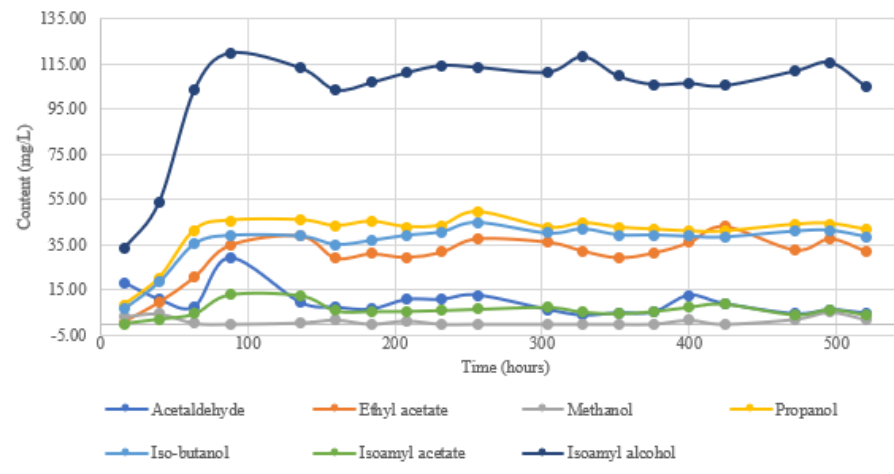

Figure 4 Formation of VOCs in the fermentation process of IPA beer.

From this study, the difference in the formation behavior of the different analytes in the different beers is clear. While Pilsen beer (Figure 1), fermented at low temperatures, needs approximately 200 hours to stabilize the concentration of VOCs, IPA (Figure 3), which is much more complex, needs approximately 150 hours, to stabilize VOCs and ensure the fall of acetaldehyde, which has a limit of sensory perception between 20 and $25 \mathrm{mg} \mathrm{L}^{-1}$ (Kobayashi, Shimizu \& Shioya, 2008; Troilo et al., 2019). Regarding this analyte, it is important to mention that in the young phase of beer, acetaldehyde is usually present in concentrations of 20 to $40 \mathrm{mg} \mathrm{L}^{-1}$, but decreases to concentrations around 2 to $20 \mathrm{mg} \mathrm{L}^{-1}$ in the final product (Kobayashi, Shimizu \& Shioya, 2008; Preedy, 2009; Nešpor et al., 2018; Troilo et al., 2019; Bortoleto \& Gomes, 2020). Still evaluating the stabilization time of the VOCs, the Witbier beer presented a time of around 150 hours as the one that reaches the stable concentrations of the VOCs studied.

Still comparing the three beers, it is possible to observe that in addition to isoamyl alcohol, the presence of iso-butanol is marked in Witbier and IPA beers Although Witbier beer is not as complex as an IPA, both of which are highly fermented, the spices in its recipe may explain the presence of these compounds with a stronger flavor in the drink.

IPA beer proves its complexity of flavor when analyzed for VOCs and compared to the other two.

\section{CONCLUSION}

By the chromatographic analysis employed in this study, aiming at monitoring VOCs during fermentation processes of different beers, it was possible to observe the analytical profiles for each style under study.

Considering the results obtained, the evidence is clear that any change in recipe and process can influence the formation of analytes during the process, which usually occurs via empirical control.

Thus, a more detailed analytical control for monitoring beer fermentation processes, at least for their optimization when it comes to the preparation of new beers, is shown to be adequate to ensure better quality and greater product identity, in response to what the consumer of this type of drink is waiting.

\section{REFERENCES}

Ambev. Discover the different types of beer. 2019. Retrieved December 14 2020, from: https://www.ambev.com.br/blog/categoria/cerveja/conheca-osdiferentes-tipos-de-cerveja/.

Anderson, H. E., Santos, I. C., Hildenbrand, Z. L., \& Schug, K. A. (2019). A review of the analytical methods used for beer ingredient and finished product analysis and quality control. Analytica chimica acta, 1085, 1-20. https://doi.org/10.1016/j.aca.2019.07.061

Bortoleto, G. G., \& Gomes, W. P. C. (2020). Determination of volatile organic compounds in craft beers by gas chromatography and headspace sampling. Research, Society and Development, 9(9), e600997746-e600997746. https://doi.org/10.33448/rsd-v9i9.7746

BOUlTON, C. A. (2019). Fermentation. In: SMART, Chris (Ed.). The Craft Brewing Handbook: A Practical Guide to Running a Successful Craft Brewery. Woodhead Publishing.

BRAZIL. Ministry of Agriculture, Cattle and Supplying (MAPA). (2019). Operating standard $n^{\circ} 1$, of january 24,2019 . Internal standard DIPOV/SDA n 01, of january 24, 2019. Official Gazette of the Federative Republic of Brazil, Brasília, DF, ISSN 1111-1111, year 3, n. 1.22, 30 jan. 2019.

CERVBRAZIL. Brazilian Beer Industry Association. Brewery market. 2018

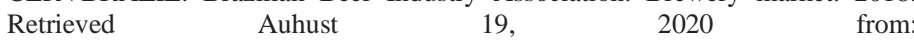
http://www.cervbrasil.org.br/novo_site/mercado-cervejeiro.

Collins, C. H., Braga, G. L., \& Bonato, P. S. (2006). Fundamentos de cromatografia.

Chen, E. H. (1983). Analysis of volatile beer flavor compounds by a dynamic headspace entrainment technique. Journal of the American Society of Brewing Chemists, 41(1), 28-31. https://doi.org/10.1094/ASBCJ-41-0028 
Gomes, W. P. C., Yoshinaga, F., \& Bortoleto, G. G. (2020). Determinação de álcoois em bebidas comerciais por cromatografia gasosa e amostragem por headspace. Bioenergia em Revista: Diálogos (ISSN: 2236-9171), 10(1).

Kobayashi, M., Shimizu, H., \& Shioya, S. (2008). Beer volatile compounds and their application to low-malt beer fermentation. Journal of bioscience and bioengineering, 106(4), 317-323. https://doi.org/10.1263/jbb.106.317

Meilgaard, M. C., Reid, D. S., \& Wyborski, K. A. (1982). Reference standards for beer flavor terminology system. Journal of the American Society of Brewing Chemists, 40(4), 119-128.

Nešpor, J., Karabín, M., Hanko, V., \& Dostálek, P. (2018). Application of response surface design to optimise the chromatographic analysis of volatile compounds in beer. Journal of the Institute of Brewing, 124(3), 244-253. https://doi.org/10.1002/jib.493

Pires, E., \& Brányik, T. (2015). Biochemistry of beer fermentation (pp. 51-53). New York, NY, USA:: Springer.

Preedy, V. R. (Ed.). (2011). Beer in health and disease prevention. Academic Press.

Skoog, D. A., West, D. M., Holler, F. J., \& Crouch, S. R. (2017). Fundamentos de Química Analítica. 9a edição. Cengage Learning.

Stewart, G. G. (2017). The production of secondary metabolites with flavour potential during brewing and distilling wort fermentations. Fermentation, 3(4), 63. https://doi.org/10.3390/fermentation3040063

Tian, J. (2010). Determination of several flavours in beer with headspace sampling-gas chromatography. Food Chemistry, 123(4), 1318-1321. https://doi.org/10.1016/i.foodchem.2010.06.013

Tortora, G. J., Funke, B. R. \& Case, C. L. (2000). Microbiologia-6 $6^{a}$ edition. Artmed Editora.

Troilo, A., De Francesco, G., Marconi, O., Sileoni, V., Turchetti, B., \& Perretti, G. (2020). Low carbohydrate beers produced by a selected yeast strain from an alternative source. Journal of The American Society Of Brewing Chemists, 78(1), 80-88. https://doi.org/10.1080/03610470.2019.1682887 